\section{Undergraduate Teaching in London}

The dominant place of London in medical undergraduate education is evident from figures given in the report of the Royal Commission last year. ${ }^{1}$ The 12 medical schools admit over one-third of the students who enter preclinical courses in Great Britain and provide clinical education for nearly onehalf of those who graduate in medicine in this country. Now in a statement ${ }^{2}$ issued last week the Greater London Council questions "the necessity of keeping in London so great a proportion of medical education."

Since the main expansion of medical education over the next few decades is to be through new medical schools in the provinces, the proportion of students in London will presumably decline. But the present burden of living and travelling in the metropolis that students have to bear should not be underestimated, for conditions are certainly more expensive and more troublesome than in most other cities. Whether or not the proportion of students declines in London owing to an increase in the numbers outside, the G.L.C. report uses the words "keeping in London" so great a proportion. This seems to be suggesting that further expansion at the 12 schools would not find favour-and on grounds of amenity for students and teachers the G.L.C.'s view deserves thought.

Looking at these problems in another way, the Royal Commission noted a multiplicity of units in which medical education is provided in London and an unsatisfactory relationship between them and the university. Among its suggested remedies was the proposal that the 12 medical schools should be merged into six pairs-Barts with the London, U.C.H. with the Royal Free, St. Mary's with the Middlesex, Guy's with King's, the Westminster with the Charing Cross, and St. Thomas's with St. George's. Not surprisingly, no announcements of marriage have yet issued from these couples, so unwittingly if not unwillingly conjugated in the commission's report. Are these proposed nuptials simply the dream of some visionary parents, or do they represent, as C. R. B. Blackburn ${ }^{3}$ has suggested, a metropolitan rather than a feudal viewpoint ?

The argument that mainly persuaded the commission of the need for amalgamation is that the excellence of an institution for teaching and research depends to a certain extent on the complexity and variety of its components, and that these cannot be attained unless it reaches a certain size. When compared with medical schools outside London those within it are reported as having "an incomplete and uneven range of clinical chairs," and as being " notably deficient in chairs of obstetrics and gynaecology, paediatrics, psychiatry and social medicine." The report rightly emphasizes the need for highly trained special staff and expensive equipment in present conditions of research, and thus is led to advocate cencentration of resources in fewer separate schools.

There follows a recommendation that each of the new combined medical schools should form a strong association with a multi-faculty university institution. The origin of most of the medical schools before London University existed in anything like its present form has given them an independent outlook that is absent from the medical schools in the rest of Great Britain. The influence of the Royal Colleges was all-

\footnotetext{
1 Report of Royal Commission on Medical Education, 1965-68. Cmnd. 3569. 1968. London: H.M.S.O.

2 Greater London Development Plan, March 1969. County Hall, London S.E.1.

- Blackburn, C. R. B., Brit. F. med. educ., 1968, 2, 111

4 Brit. med. F., 1968, 4, 594.
}

important in London, and the excellence of the schools there was largely due to that. By standing for the highest quality of medical practice they ensured that the teaching in the schools was something more than expert: it was also firmly based on the actual practice of clinical medicine. It is this special feature of the London schools-certainly not neglected in those elsewhere but receiving special prominence in London-that many would wish to see preserved in any reorganization that may be carried out.

Until recently universities everywhere lived in a glow of almost unstinted praise for the academic excellence that they embodied. Now some fresh thinking about their relation to man's real needs is being prompted. This is partly owing to the actions of a minority of students who are taking academic freedom to an illogical conclusion in an attempt to destroy it. But it stems partly also from the concern felt in developing countries ${ }^{4}$ and lately in Britain too that the work of universities, while continuing to reach up to the highest standards, must be relevant to the needs of the general population. Sometimes it is a struggle to combine utility with scholarship, but this problem is not new for medicine.

\section{Asymptomatic Bacteriuria}

"Significant" bacteriuria is defined as the presence in cleanly collected urine of more than 10,000 living bacteria per ml. ${ }^{1}$ In pregnancy it is well established that bacteriuria, even when asymptomatic, predisposes to the later development of acute pyelonephritis, ${ }^{2}{ }^{3}$ and there is a suspicion that it increases the risk of foetal death as well.

It is tempting to transfer these observations to the general population, and to suppose that screening for bacteriuria might have a similar predictive value ; but the natural history of asymptomatic bacteriuria in the non-pregnant population has not so far been determined. At pages 799 and 804 of this week's B.M.7. M. Sussmann and his colleagues from Cardiff report some interesting results obtained from a study of nonpregnant women which shed light both on the natural history of untreated bacteriuria and on its modification by treatment: These workers found that the initial differences between 100 bacteriuric women and 100 matched controls were not very great. As might be expected, previous urinary symptoms and radiological abnormalities of the urinary tract were two to three times more common among the women with bacteriuria, but in respect of blood pressure, blood urea, haemoglobin, erythrocyte sedimentation rate, and contraceptive history the differences between the groups were barely, if at all, significant. Nevertheless, since over $90 \%$ of the bacteriuric group had previous urinary symptoms-and more than $30 \%$ had radiological abnormalities-bacteriuria did not emerge from this study as a very useful early index of urinary tract infection.

The response to a short one-week course of antibacterial treatment with nitrofurantoin or ampicillin or both was compared in a sequential manner with that to placebo tablets. Though the antibacterial drugs produced a high immediate

\footnotetext{
1 Kass, E. H., Trans. Ass. Amer. Phycns, 1956, 69, 56.

2 Turner, G. C., Lancet, 1961, 2, 1062.

3 Kass, E. H., Ann. intern. Med., 1962, 56, 46.

- Asscher, A. W., Sussman, M., Waters, W. E., Davis, R. H., and Chick, S., Lancet, 1966, 2, 1037.
} 
cure rate of bacteriuria, relapse and reinfection had occurred after six months in about $20 \%$. On the other hand, about $20 \%$ of women given placebo showed spontaneous resolution of their bacteriuria over the same period. The presence of radiological abnormalities of the urinary tract seemed to encourage relapse and to prevent spontaneous cure. After one year, though there was a slightly lower incidence of bacteriuria in the originally treated group, the difference between this and the control group was no longer significant on account of further relapse and reinfection among the treated and of further spontaneous cure among the untreated. Perhaps more imporsant, the incidence of symptoms of urinary infection developing in the course of the year was, if anything, slightly higher in the group given treatment than in the group given placebo. Thus short-term treatment did not appear to confer long-term prophylactic benefit. The apparent difference in pregnancy, where there is no reasonable doubt of the longterm prophylactic value of short-term eradication of bacteriuria, might be attributed to the observation that the $p \mathrm{H}$ of urine in pregnancy is consistently optimal for bacterial growth. ${ }^{4}$

What should we conclude from these careful studies? Firstly, if the findings are confirmed, it appears that bacteriuria in non-pregnant women usually follows clinically overt urinary tract infection, and is not of much value in predicting the later occurrence of symptoms. Secondly, screening procedures to detect bacteriuria in asymptomatic non-pregnant women have no prophylactic value if used as a criterion for short-term treatment. The third conclusion is that radiological abnormalities of the urinary tract are associated with failure of bacteriuria to clear spontaneously, and with a high incidence of relapse and reinfection after treatment.

Like all provocative studies, this one asks more questions than it answers. For example, is a well-taken clinical history superior to the identification of bacteriuria in predicting later overt urinary tract infection ? Is a one-week course of an antibacterial drug long enough ? Might not a succeeding prolonged course of low-dose prophylaxis modify the natural history of bacteriuria and perhaps prevent the later occurrence of symptomatic infection? Dr. Sussmann and his colleagues have performed a useful service in showing the lines along which some of these questions may be answered in the future.

\section{Cannabis-Yet Another Teratogen?}

Since the thalidomide tragedy investigations by drug firms, pharmacologists, and anatomists have shown that a plethora of substances are teratogenic to the young of pregnant laboratory mammals. To this list T. V. N. Persaud and A. C. Ellington ${ }^{1}$ have now added extracts of cannabis as a result of their experiments on developing rat embryos. An important feature of their work is that the extract was injected intraperitoneally-a route unlikely to be used by the most hardened addict. Two socially abused drugs-namely, cannabis and L.S.D. ${ }^{2}$ - have now been found to cause foetal malformations in experiments on animals. But so do remedies such as insulin, penicillin, streptomycin, cortisone, and

1 Persaud, T. V. N., and Ellington, A. C., W.I. med. F., 1968, 17, 232. 2 Alexander, G. J., et al., Science, 1967, 157, 459.

- Rolls, E. J., and Stafford-Clark, D.. Guy's Hosp. Rep., 1954, 103, 330. aspirin, considered so valuable that those who introduced the first four received the Nobel prize. It is, perhaps, fortunate that thalidomide was developed after these substances and not before.

At present we are in the unfortunate position that a drug, whatever its potential as a therapeutic agent, will not be put on the market if it produces malformations such as encephalocele, phocomelia, and hernia in the young of pregnant rodents. There is little that can be done in Britain about this situation, since the stringent American F.D.A. regulations would undoubtedly prevent the sale of such a drug in the United States, which is the most valuable pharmaceutical market. The case of cannabis is in a different category, as it is $\mathbf{1 5}$ years since its use was advocated ${ }^{3}$ by physicians in Britain as a therapeutic agent. But in the present state of knowledge of teratology the study by Persaud and Ellington. is of only marginal relevance to the debate on the use of cannabis in man. If it has any significance for the human species the work provides one more argument against the abuse of this drug

\section{New Drug for Leprosy}

The chemotherapy of leprosy has lagged behind that of other infectious diseases-in particular that of tuberculosis, the other important mycobacterial infection of man. Drugs now used for leprosy have all begun life as possible antituberculosis agents, though they have often proved disappointing in the latter disease. The successful chemotherapy of leprosy began earlier than that of tuberculosis when in 1943 the sulphones proved to be active in man. ${ }^{1}$ This trial in human leprosy was based on their activity against tuberculosis in the guinea-pig, though subsequently the sulphones proved to be ineffective against tuberculosis in man.

Dapsone (4-4'-diaminodiphenyl sulphone) is now the standard treatment for leprosy. ${ }^{2}$ It costs only a few shillings for a year's course of treatment, and miraculously the emergence of drug resistance is rare. ${ }^{3}$ Thiambutosine-another antituberculosis drug-is the only other generally accepted form of treatment, ${ }^{4}$ though it may give rise to drug resistance..$^{56}$ Thus there has been an urgent need for more drugs against

1 Faget, G. H., Pogge, R. C., Johansen, F. A., Dinan, J. F., Prejean, B. M., and Eccles, C. G., Publ. Hlth Rep. (Wash.), 1943, 58, 1729. 2 Wld Hith Org. techn. Rep. Ser., 1953, 71.

3 Pettit, J. H. S., and Rees, R. J. W., Lancet, 1964, 2, 673.

-Wld Hith Org. techn. Rep. Ser., 1966, 319.

- Davey, T. F., Trans. roy. Soc. trop. Med. Hyg., 1960, 54, 199.

- Rees, R. J. W., Int. f. Leprosy, 1967, 35, 625

Rees, R. J. W., Int. ₹. Leprosy, 1967, 35, 625. D. W., O'Sullivan, J. F., Twomey, D., and Winder, F., Nature (Lond.), 1957, 179, 1013. Barry, V. C., Buggle, K., Byrne, J., Conalty, M. L., and Winder, F.,

- Conalty, M. L., and Jackson, R. D., Brit. F. exp. Path., 1962, 43, 650.

10 Browne, S. G., and Hogerzeil, L. M., Leprosy Rev., 1962, 33, 6.

1 Browne, S. G., and Hogerzeil, L. M., Leprosy Rev., 1962, 33, 182.

Pettit, J. H. S., Rees, R. J. W., and Ridley, D. S., Int. F. Leprosy, Willian, 35, 25.

illiams, T. W., Mott, P. D., Wertlake, P. T., Barba Rubio, J., Adler, R. C., Hill, G. J., Perez Suarez, G., and Knight, V., Int. Y. Lepros',

14 Pettit, J. H. S., and Rees, R. J. W., Int. F. Leprosy, 1966, 34, 391.

15 Browne, S. G., Leprosy Rev., 1965, 36, 17

16 Browne, S. G., Leprosy Rev., 1965, 36,9.

18 Imkamp, F. M. and Trautman, J. R., Leprosy Rev., 1968, 39, 3. 